\title{
Culture and Machine: Reframing Theology and Economics
}

\section{Philip Goodchild}

What is the relation between the economic and theological realms?

"None at all," says a certain strand of received wisdom. Such received wisdom is rooted in the Enlightenment project of the conquest of nature. Starting from the assumption that human physiology has determinate needs, and human labour has relatively uniform productive capacities, a certain 'economic nature' consisting in the production, distribution and consumption of goods and services might be known through its regularities and managed for the sake of health, satisfaction and power. ${ }^{1}$ Of course, this physiological model of the economy was disrupted by changing capacities for production enabled by inventions and the organisation of labour, as well as by changing preferences in consumption, not to mention the very changes in distribution wrought by management for the sake of profit. ${ }^{2}$ Nevertheless, a restriction of attention to distribution alone, where labour only appears under the form of supply and need only appears under the form of preference or demand, was far more promising for the constitution of an economic science - and with a few assumptions about marginal changes in production and preference, equations could be constructed to represent the laws of market, operating according to an inner necessity, like a machine. As a selfregulating machine, the economic realm functions independently of the theological. Having consolidated the separation between fact and value in the practical sphere, it was a providential boon that such a machine appeared to reunite them by promoting freedom to exchange as one wishes, enacting justice by enabling the choice of exchanges which meet the wishes of all parties and compensating each with desired benefits, and ensuring the most efficient distribution of resources by compensating the most those who create wealth. It was a further providential boon that such a market tended towards equilibrium between supply 
and demand, ensuring a stable order. Nevertheless, as an immanent machine, such a market was rarely mistaken for a god in spite of its inheritance of divine responsibilities. Even if such a pure market was more of an ideal rather than a reality, ${ }^{3}$ such perceived benefits created a moral and political obligation to extend and restructure economic life to conform more closely to this market: enclosing land, colonising near and distant places, ensuring the right to property, allowing freedom to trade and price fluctuations, removing prior social obligations that had restricted the mobility of people, goods, services and capital, supplying an appropriate quantity of the means of payment as well as tax obligations, encouraging prudent self-management through bookkeeping, and erecting state authorities to oversee development as the march to freedom. When chaos and instability followed in the wake of such progress, the ideal of the free market enabled the blame to be placed on external interference and immoral conduct. In all this, construction of the free, rational, public space of the market consisted in setting it free from the constraints of religious obligation. On this account, the economic realm, by right, should have nothing to do with the religious realm.

For the purposes of this discussion, however, the most pertinent aspect of the market is its machine-like necessity: as an immanent, self-regulating system, it needs no external guidance (beyond ensuring its freedom to operate), while it, in turn, may regulate the conduct of the material life of production and consumption. ${ }^{4}$ Just as God was no longer appealed to in order to explain the natural order discovered by science, so God was no longer appealed to in order to legitimate the practical order regulated by economy. If religion could still have a role in one's inner life, worldly necessity governed material life. For certain Neoplatonic and Protestant strands of Christianity, this liberation of the market also enabled a liberation of theology to focus on its own strictly spiritual concerns. Even those who, noting the excesses and failures of free markets in practice, sought to modulate and direct the market by means of a Christian social ethic, reproduced the fundamental dichotomy: an active and spontaneous 
subject manages a passive, material object. And perhaps even those who displace the priority of the subject in favour of the priority of culture may be suspected of reproducing this dichotomy once more. For them, material things are cultural products; cultures are rarely regarded as the product of material things. Those who subsume even markets and money back into culture, at the expense of economic determinism, may still operate by means of a dichotomy enabled by the rise of economic science. The conquest of nature appears complete, and, whether theology is regarded as legitimate master, ideological, or irrelevant, it is understood as in any case different from the ways of the world.

Now, once the ideal of a self-regulating market started to collapse - one might mention economic crises in advanced economies, advances in the discipline of economics itself to take into account behavioural, knowledge-based, and financial factors, ${ }^{5}$ deconstructions of the metaphysics of subject and object, among many other factors - then what is at stake is the emergence of an entire field of inquiry which has hitherto been invisible. This field is the common domain between theology and economics. While Kathryn Tanner and Devin Singh, in line with the wider intellectual turn from the subject to culture, primarily locate this common domain as a field of discourse, ${ }^{6}$ Tanner's work may enable us to entirely rethink what economic life is, while Singh's work may enable us to rethink what Christian theology is. For what has emerged since around the Great Financial Crisis starting in 2007 is a field called 'economic theology' whose primary task is to illuminate each of these realms in terms of the other. This is entirely different from the perennial task of a Christian social ethics, commenting on the conduct of Christians and institutions within economic life, and quite different from any purported dialogue between economists and theologians: the aim is to articulate what has been invisible to economists and theologians due to their Enlightenment assumptions. It is the rawness and newness of this as 
yet unstructured field which explains both my enthusiasm for their respective projects and the difference of my own approach.

In Christianity and the New Spirit of Capitalism, Tanner identifies the common ground for contestation between Christianity and finance-dominated capitalism in the realm of "spirit" identified as "cultural forms - beliefs, values and norms - that accompany capitalism to help shape subjects and social relations more generally to meet its requirements." (9) If Tanner's account of economic life differs so much from those given by economists in terms of markets as well as those given by political theorists in terms of freedom, rights, property, classes and laws, this is because she turns toward culture as that which directs economic conduct by encouraging people to see what they are doing as meaningful, valuable or inevitable. In what is by far the most cogent and useful summary of research on the current era of finance-dominated capitalism I have read, Tanner describes a system of governing the conduct of others through their own self-government in line with external demands. Tanner offers a bleak picture of a culture of self-exploitation in order to survive within a framework of ever-tightening competition and economic stagnation, at odds with those sunny celebrations of prosperity and liberty theoretically enabled by free market competition. The decisive difference can be found here: "Unlike simple commercial markets for exchange (of the sort Adam Smith talked about), it is not just that one does not intend the good of others; what one does out of self-interest is not in fact good for them when markets are organized by direct personal rivalry.” (191) The pertinent difference between financial and other markets is that in finance there is only one broad kind of good - expected profit measured against perceived risk - such that all exchanges involve a degree of direct rivalry. The current era is finance-dominated, not merely because finance occupies an increasing proportion of economic life or that it is often the most profitable, but because finance is decoupled from being an intermediary in the "real economy" of goods and services while at 
the same time regulating conduct within such an economy through debt. Finance-dominated capitalism is debt-driven capitalism, controlling the conduct of corporations, governments and individuals alike. Tanner exposes the dark underside of market discipline: efficiency savings are in fact achieved by shifting exposure of risks onto others while at the same time requiring more from them. Corporations are disciplined by finance in the form of both debt and equity, meeting interest payments or driving up shareholder value; individuals are disciplined by finance in the form of student loans, mortgages, car loans, credit cards and payday loans; governments are disciplined by finance in the form of their costs of borrowing to fund their basic provision of services. Instead of corporations conducting themselves in the interests of all stakeholders, or individuals conducting their lives in line with their preferences, or governments conducting their policies in line with the will of the people, the demands of economic necessity - that is, the capacity to maintain and repay debt - take priority over any other considerations. The most effective way of disciplining conduct and extracting profits is a kind of rigorous work ethic: an identification of the achievement of self-realization and self-fulfilment with an ability to meet the external demands placed upon one at any moment. In contrast to the old Protestant work ethic of work for work's sake, such work is not self-directing; instead, one's very self is a kind of economic property, human capital, the ability to generate further profit and maximise one's personal growth.

In this new context, profitable capital consists primarily in culture: the government of others through their own self-government. There are good reasons for turning to culture in this way. Instead of economic life being shaped simply by meeting demands for goods and services, it is shaped by meeting the demands of making profits and repaying debts. Instead of political life being shaped simply by democratic deliberation, it is shaped by conformity to economic necessity in the form of international capital markets. Instead of individual life being shaped simply by autonomously-generated life projects, it is shaped by the project of 
becoming human and moral capital, ready to meet the demands of the moment. In each case, the common feature is the government of others through their own self-government - a structured process of self-cultivation. Moreover, if one pulls back the veil of finance to inquire about the creditors who are pulling all the strings, one merely discovers exactly the same kind of human subject and work ethic, indeed, if anything, a subject capable of bearing more intense pressures and faster demands. There is also another reason for finding this cultural account compelling: it can be extended beyond the distinctively economic sphere of life aimed at profit, being applied for the purpose of intensive management of public institutions. Tanner refers to the contemporary management of universities as a training ground for the corporate mentality (76). The daily life of a professor consists in an exercise of pastoral power: selection of candidates, guidance and coaching towards benchmarks of success, grading papers and examinations, awarding competitive grants, scholarships, positions and tenure, refereeing journal and book publications. Each of these mechanisms facilitates confession and self-governance, where only the most dedicated can achieve success - the aim now being success, rather than autonomous self-cultivation. Such a culture is widely taken for granted; few would wish to return to a liberal model of education with its excesses. In short, given this rejection of liberalism, disciplined self-governance is not merely an external imposition: it is an object of desire. Moreover, it is only natural for scholars to identify that which structures their daily experience as that which is at work elsewhere.

The other aspect of Tanner's account which I find fascinating and compelling is the analysis of conduct in terms of a relation to time and others. Within the constraints of competitive markets, and threatened by the very considerable risks of failure and loss, people become bound to an unalterable past, an agreed contract or debt. To ensure one's place and capacity to earn, total commitment is required, or what amounts to the same thing, offering 
evidence of total commitment. Attention is focused on a very narrow present in response to its urgent demands. Any radical change in the future must be forestalled, since the future needs to be constructed to meet the demands of the present. Each person must bear responsibility for their conduct and fate alone. Tanner provides a rich and detailed picture of what it means within contemporary capitalism to have one's life governed by destructive and self-destructive practices. If this is life under sin, where, irrespective of one's intentions, one cannot free oneself from constraint, then it would seem natural to turn to a gospel of repentance and grace. Within the common domain of the conduct of time, Christianity can offer a direct challenge by imparting a different spirit, a whole new way of being: being liberated from the past, oriented in commitment only towards God, reunited from dispersal in separate presents to the eternal consciousness of seeing things as a whole, ${ }^{7}$ anticipating surprise in the future, and cooperating rather than competing with others.

Here, I must confess, I have struggled to discern the force of the challenge it makes. Could it not be, for example, that force lies on the side of the new spirit of capitalism, and Protestantism, while it cannot be idolatrously identified as the spirit of contemporary capitalism, is destined to be transmuted into one business venture alongside others? After all, Tanner's account of the daily practice of repentance and conversion is extremely familiar, conforming in terms of recommended conduct to centuries of Protestant sermons. Nowadays Protestants rarely rise up to overthrow capitalism - and such protests, frequent as they were in the past, having largely fallen silent. ${ }^{8}$ Capitalism is not Christianity; but in the battle to determine which will govern daily conduct, it appears, if only for our present brief moment in history, that Protestant Christianity is on the losing side. Moreover, the Protestant motifs of freeing from past obligations, offering total commitment, focusing on the present, anticipating future benefits, and adapting to the requirements of others - irrespective of one's given role in society - may train the most malleable kind of subjectivity which can be 
captured and put to work by extrinsic forces. Even so, where most accounts of this Christian conduct are articulated in the discourse of scripture, doctrine, ethics, or the practice of holiness mediated by daily prayer and Bible study, Tanner's account disciplines itself to avoid any such mediation, being structured instead by the discourse of Augustinian Neoplatonism. ${ }^{9}$ While monetary and economic metaphors are celebrated and used to the full, the only material practices I could find raised for consideration were quitting one's job as a mortgage broker (131), giving up competition (203), and the rejected radical options of refocusing on household life, a general strike, or a debt strike (209). I do not doubt that Tanner would not exclude adopting Catholic Social Teaching or a Protestant social ethic as authentic if imperfect ways of living out one's Christian calling. Yet I would appreciate some further clarification of why the conscious strategy has been adopted of refusing to discuss how faith offers remedies for the actual ways in which people are constrained to exploit others in the ways she has described so copiously.

Despite the shared discourse, the book is structured according to a sharp division of labour between economic projects, to be pursued within the culture of finance-dominated capitalism, and a "religious project" (210) articulated in terms of "value in God's eyes." (206) While the former is explained in rich, concrete detail, the latter is underdetermined, since it is God's work of grace already achieved rather than human work anyway; the human contribution seems to be limited to an admission of failure. One prays and repents on a daily basis; yet one continues to go to work and borrow when necessary - at least now with a cleared conscience. I am at a loss to understand what the devout Christian is to do with respect to the ordering of cooperation to fulfil human needs without exploiting others; this does not appear to be a significant part of her "religious project". How might a Christian CEO, financial trader, carwash attendant, homeworker, or unemployed person differ in any significant way from the non-Christian? If it is a matter of refusing to be competitive, then 
the natural outcome would be that devout Christians fail to be appointed or fall out from positions of influence, leaving those who are much more willing to govern themselves according to the new spirit of capitalism to further intensify its reach and hold. This hardly constitutes a challenge.

By refusing to discuss any material mediation of Christian life, Tanner's project to articulate a pure Christian conduct, based around a grace which is entirely unlike the ways of this world, is premised upon, and helps to maintain, that sharp separation between economics and religion which is so characteristic of the Protestant world. "Grace remains untouched," (133) safe and sound, immune to the struggles of the world, and in imitation of God, Christians are to become more and more unlike anything within the world - perhaps progressing towards being untouched in their souls. Both grace and the Christ who is to be imitated appear in Tanner's account as transcendent signifiers, above and beyond any worldly or cultural meaning. I fear that this is the gospel of Neoplatonism rather than the gospel of Christ crucified, who was more than touched; he was, as the gospels repeatedly say, "handed over". ${ }^{10}$ Likewise, the Eucharist is not untouched but consumed. Since the Christian gospel was first articulated in primarily economic rather than metaphysical terms, I suspect that it contains a theological imperative to rethink the sharp division between material conduct and grace.

It is my philosophical difference from Tanner, however, that I wish to pursue just a little further. For it seems to me that the dynamics of contemporary capitalism she describes cannot be accounted for fully within the framework of culture understood in a Foucaultian way as government of others and government of self. For the capitalist spirit only arises under specific conditions of market discipline. Even if the market as a mechanism for bringing supply and demand into equilibrium is no more discussed than the market as a moral ideal in Tanner's account, the market is still omnipresent as a machine, external to all cultural 
variation, imposing its implacable demands. Again and again, throughout her account, Tanner appeals to a necessity which, in Marx' terminology, is determining in the last instance: "Whoever does not adapt his manner of life to the conditions of capitalistic success must go under, or at least cannot rise." (26) This necessity arises from a machine with the following structure: money and finance, as intermediaries in all transactions, measure, transact and seek one sole good, profit. Profit has no culture: it is measured by money alone. ${ }^{11}$ In a first move, financial transactions can be decoupled from interactions with producers and consumers in order to become interactions between financial agents themselves, making money directly from money through credit and debt. In this way, money and finance escape from the constraints of production and consumption, just as capital can likewise be removed from the legal constraints operating within any given territory. Finance is deterritorialized; its freedom consists in its liquidity as a decoded flow. The outcome of this disintermediation, when profit opportunities are scarce, is initially a shortage of money for investment and consumption. In a second move, even though finance is not itself productive, it can fall back on production and consumption as credit and debt to substitute for the shortage, imposing the requirement of profit maximization. In this account, while finance has a culture and is a product of culture, it is better understood as a machine in the sense in which Marx spoke about human alienation and subordination to a machine of its own making. It operates according to the necessity generated by decoupling, liquidity and debt in the context of physical human need. It becomes the exterior environment of all business, culture, territory and government. This is capitalism as a machine. ${ }^{12}$

Yet what is the Protestant spirituality Tanner describes if not a process of decoupling, liquidity, and debt (to God for the gift of grace) in the quest for the power of salvation? Perhaps salvation would be better understood as something offered to others, not appropriated for oneself. Returning, however, to Tanner's account of capitalism, what she 
describes is in fact a conjunction of culture and machine: ${ }^{13}$ like the sorcerer's apprentice, like Goethe's Faust, culture conjures up a machine, through a kind of alchemical magic, which breaks free and dominates it; in turn, the machine relentlessly drives a deeper and deeper appropriation of a culture which it itself selects.

A first implication is that Weber's account of the reversal of means and end by appealing to religious beliefs to explain apparently irrational conduct becomes unnecessary it is another typical Enlightenment gesture of constructing religion as the other of reason. Its enduring appeal had largely been for theologians and cultural theorists who saw in it an escape from Marxist materialism, rather than its historical veracity. While the Protestant work ethic may have been a familiar sight during the nineteenth and twentieth centuries, perhaps as a way of adapting Protestantism to capitalism, the Weberian thesis itself surrounding the origins of capitalism - always a rather tentative one of 'resonance' - is historically untenable: for example, instead of using accumulated wealth for thrifty ends, the first factory owners were debtors who mortgaged their land in order to build factories in the countryside. ${ }^{14}$ Not that this requires any return to a materialist account of economic base and religious superstructure - the actual history of the relation between Puritan sensibilities and thrifty economic conduct is far more interesting: it revolves around credit. ${ }^{15}$ To offer just a hint at what is at stake here, in the Puritan era wealth consisted not primarily in possessions, money, or the means of production, but in creditworthiness. Daniel Defoe described this perfectly in a passing remark about the impossibility of conducting trade without credit (intended primarily in the sense of deferred payment, yet evoking so much more): ${ }^{16}$

He that gives no trust, and takes no trust, either by wholesale or by retail, and keeps his cash all himself . . . so no body is in debt to him, and all his estate is in his shop; but I suppose the Tradesman that trades wholly thus, is not yet born, or if there ever were any such, they are all dead [emphasis added]. ${ }^{17}$ 
Notice just how deep an imbrication of wealth, trust, holiness, credit and grace is entailed in keeping one's estate in one's reputation before others as well as in their obligations to oneself. This mutual dependency and deep imbrication has not gone away; it has merely been institutionalised within money, banking and finance as the dynamic force of capital, the hidden daemon of the machine. ${ }^{18}$

A second implication is that when faced with an oncoming destructive machine, it is largely useless to speak about a change in self-governance (although to repent, weep and pray may be the best that some can do, as John the Baptist taught). It is far better to take the machine apart, see how it works, and see if one can make modifications to its components (even if this just a matter of drawing circles in the sand, like Archimedes at the moment of his death). A study of the internal dynamics of finance, money and banking is more significant than a study of their culture. A third implication is that capitalism may never have been what we thought it was: it has always been finance-dominated. Debt and mobility have been part of human life for a good five millennia, and its mechanisms for controlling subjectivity are no more new than the risks involved in living a precarious life. ${ }^{19}$ Since all the main elements of finance were present prior to the rise of industrial capitalism, capitalism - perhaps even in its ancient Sumerian and Babylonian forms - has largely been financed-based. As David Graeber has pointed out, even in Marx' day in London there were far fewer factory labourers than there were street-hawkers and prostitutes, while in the colonies, the modern world was largely built by slaves, bonded labourers, and debts peons. ${ }^{20}$ The spirit of capitalism described by Tanner is not entirely new. What has changed might be the extent of markets, the liquidity of assets, the turn to the propertied classes as the primary resource for exploitation, and the unification of cultures of self-government, but just as debt, competition, and precariousness have been historic means of exploitation, so also has indebted subjectivity, involving the relation to time and others that Tanner describes. It is the post-war 
period of tight capital control, rapid economic growth, and a functioning welfare state that is the historical exception rather than the norm.

Now, one of the many points over which I do in fact agree with Tanner is over refusing a certain kind of Platonic legacy consisting in idealising the past (51): all Christians are continually enmeshed in sin. Such a refusal, I believe, is shared by Singh, motivating his study of the fourth century nexus of religion and economics, Divine Currency. Far from accepting a pure theological origin for authorisation and legitimation of doctrine, practice and conduct, Singh charts the messy involvement of Patristic theology with the power practices and techniques of exploitation conducted by the Roman empire. If theology inevitably drew its discourse from the cultural forms available to it, including practices of economic administration, then it preserves the structure of such practices for future eras. Singh explores a two-stage process: the language about the nature and function of money has been taken up by theology; subsequently, theological language about debt, payment and exchange are imported into descriptions of what money is, should be, and how it is deployed (18). As sanctified discourse, used metaphorically, theology has apparently baptised and purified such language from all its exploitative connotations: if God is the true economist, then exploitative cultural forms are imperfect and sinful imitations of the divine economy, while more just economic practices can be devised by imitating the divine model. Yet what Singh implies is that if economic language itself is used to explain this process of conversion, reminting Christians as God's coins, then the coin produced remains an alloy rather than pure silver. The very language of purification becomes a technique in the authorisation and legitimation of evolving customs and practices which continue to have exploitative effects - about which the Christian now need have little consciousness or concern, since their task is more faithful imitation of God who, by definition, cannot in any way be corrupt. I might be tempted to call this a distinctively Christian form of idolatry, one that generates its own image of God 
through its own penitence (also one largely evaded by Judaism and Islam with their rather different cultural practices for maintaining the holiness of God) - it being a Christian prerogative endorsed by Tillich's Protestant Principle (which finds echoes in Tanner's account) to accuse Christianity itself of corruption. Singh is more consistent than I in declining such temptations - perhaps they are a product of the very mechanisms of monetary exchange and purification he explores. Instead, he calls for greater self-reflexivity, investigating how "theological and ethical engagements have already helped construct the circumstances against which they protest." (10) At stake, here, is perhaps the very character of theology itself. Let me state at the outset that, in contrast with much of the Christian tradition, I believe there are good Christian reasons for risking this reflexivity: if Christ was "handed over" to the ways of sinful men, it is very likely that theology both is and should be too. My wager is that if Christian theology holds any wealth, it is not the kind of wealth it keeps in its own shop; such a wager may be the very meaning of faith.

The crucial axis of Singh's homology between money and Christ is sovereign power: money is "a sign and representation of sovereign power inserted into a space or territory to aid in the governance of subjects." (5) For to pay for goods and services with nothing but a coin bearing the stamp of a sovereign is to declare that one's suppliers are subjected to sovereign power: they acknowledge that subjection insofar as they provide goods and services for just a token, as if rendering tribute to one who bears the seal of authority of the sovereign power. Of course, in this process, the coin is actually handed over, and the supplier now becomes the one who will bear authority in a future exchange. Yet eventually, this authority will have to be accounted for: each person under sovereign authority is required to render coins back to the sovereign power in taxation - and as a result, demonstrate that they have engaged in deferential conduct by providing goods and services at the mere sign of sovereign power. In the meantime, all are alike subjected under sovereign power and for this 
reason are able to offer goods and services to each other in exchange for tokens marking sovereign approval and authorisation. As Singh explains, money undergirds and is empowered by a notion of territorial and ideological unity, utilising the same tokens of power, measure and value issued by sovereign decree (50). The resonances with Christian life and practice are striking, even if no coins are handed over: Christians receive divine grace in baptism, being marked with the sign of the cross signifying that they are now under divine sovereign power. In collective life, Christians then act in service to one another, well aware that in serving the least of their brethren they are actually rendering service to Christ. At the end, Christians will have to give account of their deeds in the body, showing whether they have actually taken up their cross on a daily basis. In the meantime, all are alike under the sovereign power of Christ - in Christ there is no longer Jew or Greek, slave or free, male or female - and are thus bearers of Christ's sign, deserving to be served under his authority. One might suggest that in this way Christianity prepares the ground for empire, constructing subjects willing to construe themselves as servants to whatever the moment demands, for since service is universal, actual demands bear authority whatever their provenance. When there is a job to be done, those who are selected are those who can be relied on, who can commit themselves wholeheartedly, bearing the highest cost of physical and mental anguish irrespective of the task $\mathrm{k}^{21}-\mathrm{I}$ am suggesting that the special forces soldier of today offers the best embodiment of this one particular aspect of Pauline subjectivity (even if they are unlikely to undergo quite as extreme yet fortuitous a set of experiences as Paul himself).

This military analogy is far from coincidental: it would seem that the first coins were issued to mercenaries by despots. If one wonders why mercenaries might be willing to fight and risk their lives for the sake of mere tokens, prior to the installation of anything like a monetary economy, then the answer is clear: such tokens, issued by the grace of the sovereign as symbols of patronage and favour, enabled the mercenaries to participate in the 
prestige and benefits of this sovereign power - a power that actually consisted in that of the mercenaries themselves fighting and acting together as one group. It is such delegated and extended symbolic power which is the focus of Singh's interests, and lest I continue to deviate too far from his own account, let me cite in full his concise summary of the militarycoinage-taxation complex:

The tax circuit gives value to money, and the power to tax reflects sovereignty. Without taxation, money as we understand it would not exist. The imposition of taxes renders monetary tokens meaningful and valuable. As noted, monetary tokens have typically been disseminated via occupying military forces or civil servants, as signs of ruling power imposed upon the populace in exchange for goods and services. The state as guarantor declared that it would accept these arbitrary tokens back as a way for its subjects to discharge their debt of economic fealty. In so doing, it established a monetary circuit, an ebb and flow of tokens that marked relations of credit and debt within a territory. Taxation established the decreed exchange proportions, indicating the abstract value of money, as the state declared other acceptable means of in-kind payment in terms of their equivalences with the money standard (46-47).

This is the state theory of money, invented by Georg Knapp and expounded today by Randall Wray, according to which markets and debts are enabled by the sovereign and military power of the state. It describes a mechanism of circular flow (a machine) by which a sovereign power, through its own initiative, grace or patronage, can expand its territory, its control of the populace, and its profit in return. Each sovereign power demonstrates its authority on accession by issuing a new set of coins; it demonstrates its authority over a newly conquered populace by extending the circuit of coins. It is this mechanism which has been taken up and reproduced in symbolic terms within the discourse of Patristic theology, especially as articulated by Eusebius in his homology between Constantine and Christ, announcing the 
accession of each as the coming of divine rule. It is a mechanism which is taken up by Gregory of Nyssa in his bait-and-switch model of atonement, where Christ is the gracious payment which overcomes the previous Satanic sovereign. It is a mechanism which seemed only too natural to theologian bishops since it had already been taken up in the spiritual discipline of almsgiving for the sake of salvation - one that has been occluded especially in Protestant thought, but as Countryman and Brown have shown, was central to the early church (and it may indeed still motivate a Protestant work ethic). Almsgiving was directly tied to receiving treasure in heaven since it imitated Christ's own self-giving. Bishops, who were responsible for the collective purse and allocation for the poor, rose to leadership through their pastoral responsibilities; the poor, previously overlooked in Roman conceptions of public benefaction, patronage, and gift-exchange, were invented as a public concern by Christian life and practice and motivated to be incorporated into the life of the Church. In such practices, it was the handling of real money which directly impacted one's eternal, symbolic destiny.

One of the great merits of Singh's account is that, unlike Foucault's account of the origins of modernity in Christian pastoral practices of confession, and unlike Agamben's account of the origins of modernity in Trinitarian considerations, he engages with the concrete economy in the form of the exchange of material goods, resources and money. While I find Foucault's and Agamben's projects to be inconsequential and unconvincing, Singh's wager that "monetized theology has lent itself over the centuries and in various permutations to the growth of economic thought and practice in society" (7) seems rather more plausible - even if it could only be established by a thorough study of later centuries. Once sanitised and converted into an ideal model in theological discourse, the circular flow mechanism can be put to work without self-questioning in colonial conquest, in the name of the gracious offering of the benefits of trade, civilisation and development, as well as in 
capitalist investment, graciously investing one's own wealth in expectation of a return while maintaining that it is the other party who is enabled to prosper thereby. What might be troubling here is less extending the benefits of development, enlightenment, stable governance, and productive capacity than an inattention to the concomitant subjugation involved in taxation and debt - the contemporary experiences of which have been so adequately described by Tanner, but do not necessarily differ in kind from the experiences of colonial subjects for centuries at the hands of devout Protestant soldiers, slave-owners, venture capitalists, colonists and imperial civil servants. What if the new spirit of capitalism simply reveals a very old spirit of Christianity? This troubling feature reaches back to the Christian discipline of almsgiving itself: in Augustine's struggle to defend the established practice of regular almsgiving, for the sake of both the salvation of the rich and the orderly and consistent support of the poor, against any Pelagian return to the gospel teachings of complete and once for all divestment, what gets missed is the Pelagian complaint about the source of wealth itself in conquest, theft, exploitation and the inheritance of their benefits. ${ }^{22}$ Whatever its source, wealth could be sanctified when offered back to God as alms for the poor. Likewise, sin can be redeemed when offered symbolically in repentance back to God. Such sanctification often merely draws a veil over ongoing injustice. Perhaps theology itself, when constituted as a discourse abstracted from material practices, is merely another form of such sanctification, extracting a semantic surplus value - "value in the eyes of God" - from conduct that has direct consequences for self and others. Furthermore, perhaps the cultural turn itself, as a totalising move intended to encompass the entirety of material practices under the form of conduct, is merely an incarnation of such theology by another name, locking sovereignty in conquest with sovereignty, right against right, conduct against counterconduct, power against resistance. ${ }^{23}$ After all, what do scholars do but translate the whole of human experience into the semantic realm? What I fear is the drawing of a veil over what 
cannot be reinscribed within a frame of cultural meaning - a veil which may continue to render certain aspects of life all but invisible.

On this note, it is now time to return to indicate some difference from Singh. The mechanism at the heart of Singh's account is the state theory of money, and this of course is by far the most pertinent to the expansion of the Roman empire, the origins of Christianity, and the fourth century conjunction of economic practice and theological discourse. It situates the function of money entirely in relation to a sovereign territory subject to governance. Yet coins also circulate widely beyond their territories of issue if people are willing to accept them in exchange; they can also be replicated by anyone who writes a promissory note, an IOU, which can in turn be transferred by its recipient when paying a third party. The recent consensus of scholars, as Singh is well aware, is that not only is it the case that the barter theory of the origins of money is untenable, but that money and its value are constituted by the conjunction of state, market, and credit. ${ }^{24}$ In other words, in addition to its symbolic functions which reinforce and enact sovereign power, money also has the tendency to escape the control of any territory as well as to reconstitute and reproduce itself through transferrable debts - it has emergent dynamics. The most that governance of money can hope for is some stability through controlling interest rates and inflation; sovereignty is exposed to forces beyond its control. In a most interesting recent article, Singh has explored how sovereignty itself is established and maintains itself in and through debt ${ }^{25}$ - this seems to me to be a considerable advance over the paradigm operative in Divine Currency. There are other phenomena at work beyond the governance of self and governance of others.

If one returns to the Christian symbolic register with these considerations in mind, one may note how unlike Roman imperialism Christianity was. In serving one another, no coin or currency is handed over. The Eucharist is not a circular flow nor a medium of exchange. The poor are not (necessarily) required to pay tithes back to the Church. Christ himself was 
handed over. The material logic is different, even if this has often been obscured by the homologies in discourse. Christianity is more than a regime of governance of conduct, more than a regime of grace and obligation; it involves direct exposure to the forces of the outside.

This, I believe, is the conclusion that can be drawn from Singh's work: Christian theology has never been able to constitute an enclosed, ordered, and governed semantic territory; it has always been exposed to disturbances from outside. Of course, in response to such disruption, the main thrust of theological endeavour has been to seek the semantic coinage which will effectively establish complete divine dominion, a core of sovereign grace untouched by the world. That such a response is driven by a lack of faith could only ever be a minority opinion. That Christian theology could be pursued beyond its own semantic register within territories where it holds no privilege or sovereign power of conversion is a position that is almost imperceptible.

Let me conclude by indicating a path economic theology might take from here. The human condition is such that we are exposed to forces beyond the conduct of ourselves and others - the flow of time, ecological instabilities, credit crises, abstract machines, sin and grace. Finance-dominated capitalism, currently unchecked in its machinic necessity, is producing the apocalypse of climate change and biodiversity loss which human civilisation in its current forms may not survive. By means of decoupling, liquidity, competition and debt, it is reconstituting economic relations as a war of all against all. At the same time, as neoliberal subjects assert more volubly their unmediated rights, agreement through democratic deliberation is harder to achieve, and the clash of populisms under conditions of scarcity is a harbinger of the potential for future total wars.

A first task is to locate the common domain of economics and theology in the human relation to what is beyond its control - not in discourse, culture, governance, or desire, but in 
trust, credit and faith. This new foundation enables a rethinking of Christian theology as constituted by its conduct towards what lies outside it, where credit and faith are required: at once the material conditions surrounding the satisfaction of human needs and the spiritual conditions enabling the distribution of care and attention, credit and evaluation, and trust and cooperation. Alongside this, a new story of the origins of capitalism out of Christianity can be told once credit, which hands over care, value and trust, is ordered by debt, a promise of definite value by a definite time. In a fundamental reversal, capitalism emerged out of Christianity by offering an alchemical multiplication of debt as a basis for trust. I have tried to offer an account of this in my forthcoming Credit and Faith. ${ }^{26}$ A second task is to take apart the capitalist machine as an ordering of trust, in itself a theology, exploring the function of the ideology of the market as a component in its structure, the disequilibrium dynamics by which it actually functions, and the focal role of finance as at once a failed means of salvation seeking to restore the ideal market and at the same time the condition of possibility of modern economic life. I have tried to offer an account of this in my forthcoming Economic Theology. Once the common domain between economics and theology has been established, and credit and faith are understood in relation to each other, a third task is to rethink the conditions which underpin a more creditworthy allocation of trust. A renewed ontological framework, disclosing a deeper meaning for appropriation and wealth, for participation and power, and for grace and necessity, has been offered in my forthcoming Metaphysics of Trust.

Of course, many might seek to reassure me that culture does indeed encompass everything, that there are no decoded flows or machines, and conduct can indeed be governed and reformed - such might be read as the implicit message of Tanner and Singh's projects if ever called to address the thesis of my Theology of Money. ${ }^{27}$ My response is simple: come back to me when you have succeeded in governing the flow of time. In the meantime, do not disturb my circles. 


\footnotetext{
${ }^{1}$ This was the starting point for modern economics with William Petty in the seventeenth century.

${ }^{2}$ Margaret Schabas, The Natural Origins of Economics (Chicago, IL: Chicago University Press, 2005).

${ }^{3}$ Karl Polanyi, The Great Transformation: the origins of our time (London: Gollancz, 1945).

${ }^{4}$ Newton's laws of mechanics were the paradigm, as explored in depth by Philip Mirowski, More Heat than

Light: Economics as Social Physics, Physics as Nature's Economics (Cambridge: Cambridge University Press, 1989)
}

${ }^{5}$ John Cassidy, How Markets Fail: The Logic of Economic Calamities (London: Penguin, 2010).

${ }^{6}$ Tanner, Economy of Grace (Minneapolis, MN: Fortress, 2005) x; Devin Singh, Divine Currency (Stanford, CA: Stanford University Press, 2018) 18; both, however, discuss material practices as part of culture.

${ }^{7}$ It seems to me no coincidence that a theologian has produced the best account of the experience of contemporary capitalism: only theology has the aim of a holistic vision, instead of specialised dispersion.

${ }^{8}$ R.H. Tawney, Religion and the Rise of Capitalism (London: J. Murray, 1926).

${ }^{9}$ This is, of course, a selective appropriation of Augustine, demurring from the famous turn against

Neoplatonism in Confessions Book VII since one knows all too well whence his conception of order led - an extremely worldly patriarchalism.

${ }^{10} \mathrm{I}$ am not simply taking the side of the likes of Moltmann and Soelle here; my primary inspirations are W.H. Vanstone and Kosuke Koyama.

${ }^{11}$ Liquidity is the relevant feature here: exchanging one instantiation of value for another..

${ }^{12}$ Gilles Deleuze and Félix Guattari, Anti-Oedipus (London: Athlone, 1984).

${ }^{13}$ One of her key sources here, Maurizio Lazzarato, reintegrates Foucault's theory of governance back into Deleuze and Guattari's account of capitalism in terms of signs and machines.

${ }^{14}$ Andro Linklater, Owning the Earth: The Transforming History of Land Ownership (London: Bloomsbury, 2015) 181.

${ }^{15}$ Craig Muldrew's historical study of seventeenth century England offers the most decisive refutation of Weber: The Economy of Obligation: The Culture of Credit and Social Relations in Early Modern England (Basingstoke: Palgrave, 1998).

${ }^{16}$ As also did Benjamin Franklin in the passage quoted at the opening of Weber's Protestant Ethic, although Weber's selective quotation misses the wider point being made.

${ }^{17}$ Cited in Muldrew, The Economy of Obligation 129.

${ }^{18}$ There is no more space to expand on this hint here, even though it may require us to rethink the entire relation between theology and economics as well as the origins of capitalism and the nature of money.

${ }^{19}$ David Graeber, Debt: The First 5,000 Years (New York: Melville, 2011).

${ }^{20}$ Graeber, Debt 350.

${ }^{21}$ This is a polite paraphrase, removing expletives, of the primary message communicated by Ant Middleton, former British special forces operative, in his television program simulating special forces selection.

${ }^{22}$ See the discussion in Peter Brown, Through the Eye of a Needle: Wealth, the Fall of Rome, and the Making of Christendom in the West 350-550AD (Princeton, NJ: Princeton University Press, 2012) ch. 19.

${ }^{23}$ For a critique of its totalizing effects, see Terry Eagleton, The Idea of Culture (Oxford: Blackwell, 2000). 
${ }^{24}$ For example, Graeber, Debt; Ole Bjerg, Making Money: The Philosophy of Crisis Capitalism (London: Verso, 2013); Nigel Dodd, The Social Life of Money (Princeton, NJ: Princeton University Press, 2014).

25 'Sovereign Debt', Journal of Religious Ethics 42 (2): 239-66.

${ }^{26}$ Philip Goodchild, Credit and Faith (London: Rowman and Littlefield International, forthcoming); Economic Theology and Metaphysics of Trust will follow at six monthly intervals from the same publisher.

${ }^{27}$ Goodchild, Theology of Money (Durham, NC: Duke University Press, 2009). 